\title{
THE SWOT MODEL AND THE ROLE OF THESE ACTIVITIES TO THE TRAINING OF THE FUTURE SPECIALISTS IN EXPERTISE AND QUALITY CONTROL OF MILK AND DAIRY PRODUCTS
}

\author{
Mihaela, TIŢA ${ }^{1}$, Letitia, OPREAN ${ }^{2}$, Ecaterina, LENGYEL $^{3}$ and Ovidiu, TITA ${ }^{4}$ \\ 1"Lucian Blaga" University of Sibiu, Romania, titamihaeladriana@yahoo.com \\ 2"Lucian Blaga" University of Sibiu, Romania, letitia.oprean@ulbsibiu.ro \\ 3“Lucian Blaga" University of Sibiu, Romania, ecaterina.lengyel@ulbsibiu.ro \\ 4“Lucian Blaga” University of Sibiu, Romania, ovidiu.tita@ulbsibiu.ro
}

\begin{abstract}
The present drafts regarding the quality of milk and dairy products, define it as a controlled act of creation with known accuracy that can be reached by applying constitutive control systems of the processing technologies that are present in all proceeding phases of the product. In order to achieve the purpose and to apply it in the production process by students - future specialist, we use as a teaching-learning technique the SWOT Analyze. The SWOT analysis is an efficient method that is used in the teaching technique, especially when planning the strategy in order to identify the potentials and the priorities.
\end{abstract}

KEYWORDS: SWOT analysis, strategy, milkprocessing

\section{INTRODUCTION}

Engineering education has special needs when offered in a distance mode, including consideration of how best to provide laboratory experiences [1]. Recent trends in engineering education have led to an increased use of class projects for teaching engineering design [2]. It has also long been said that engineering programs should graduate engineers who can design effective solutions to meet social needs [3]

The central task is to equip Europe's populations - young and old - to play their part within the Knowledge Society, in which economic, social and cultural development depend primarily on the creation and dissemination of knowledge and skills [4]. The European's traditional education was always modeled by a history that showed that it is more prudent to not expose yourself, but also to not calm down the fever of a hurrying century, living with the illusion that there is time for everything [5].

In the past ten to twenty years, manufacturing and engineering fields have undergone dramatic changes, for example, the emergence of international competitors and the invention and application of computer-based advanced technologies [6]. The impact on engineering education is due to shifting from industrial towards post-industrial engineering [7]. Everyone involved in engineering education, both students and teachers, know, that in order to get a degree, students have to pass examinations. Examinations are part of the educational culture and this seems to be something like a law of nature [8]. Engineering education has had a rich tradition of educational innovation, but until the 1980s assessment of innovation was typically of the "We tried it and liked it and so did the students" variety [9].

The modern engineering profession deals constantly with uncertainty, with incomplete data and competing (often conflicting) demands from clients, governments, environmental groups and the general public [10]. Lectures and laboratories are the traditional way of delivering engineering education. These two methods are efficient, yet neither can be easily scaled to teach large numbers of students [11]. In recent years, new findings in cognitive processes and behavioral psychology have demonstrated the limits of lecture, and alternatives to augment its effectiveness have been demonstrated, including laboratories and cooperative learning [12]. How much a given student learns in a class is governed in part by that student's native ability and prior preparation but also by the compatibility of his or her learning style and the instructor's teaching style [13]. To be able to innovate here and now engineering education it is necessary to define the target: how would look like an educated engineer in the future KS. (Bizarre designations of subfields become common: after "system" and "genetic" engineering in the XXth century, now "memetic" is added too.) [14]. The modern engineering profession deals constantly with uncertainty, with incomplete data and competing (often conflicting) demands from clients, governments, environmental groups and the general public [10]. Food engineering is the multidisciplinary field of applied physical sciences combined with the knowledge of product properties [15]

Engineering academics have historically worked closely with the federal government by serving on national advisory boards in education and research and by taking on important "rotator" The drivers of systems management include the external opportunities and pressures, and the internal strengths and weaknesses of a given systems engineering organization, as well as the organizational leadership and culture associated with the organizations associated with the tasks at hand [16]. Corporations and employers have frequently and publicly complained about the lack of professional awareness and low levels of communication and teamwork skills in engineering graduates and about the failure of universities to use sound management principles in their operations [17]. 
New curriculum models and designs are based on an organized list of learning outcomes identified as critical in the education of new engineers [18]. Essentially, a teaching style that is action-oriented, encourages expert inertial learning, problem solving, project-based learning, creativity, and is supportive of peer evaluation [19]. The development of such methodologies has required field testing, over the past fifteen years, different approaches and strategies to attain and maintain the involvement of professors and students in team-oriented, effective teaching activities, such as early-design projects [20].

The knowledge society considers education and training among the highest political priorities. In order to achieve the goals set for 2010 by the Bologna Process national education bodies called upon universities to establish performance indicators to measure progress towards these goals [21].

A system of education is closely woven into the fabric of the society within which it operates [17]. In the education system, information sharing is needed (data, knowledge, etc.) in order to support the various processes that take place at the managerial level [22]. In the educational process, the educational opportunities combined with the important element 'the student' result the educational product, the specialist in the field [23] .

The "Lucian Blaga" University of Sibiu has a tradition of more than 220 years, starting with the Orthodox theological higher education institution founded at the end of the 18th century for the training of future clergymen from the Romanian Episcopacy of Transylvania [24]. The name was changed in 1995 to "Lucian Blaga" University of Sibiu so as to honors one of Romania's greatest thinkers, "Lucian Blaga" [25]. A required course for elementary education majors at "Lucian Blaga" University of Sibiu (Romania), "Quality Control of Dairy Products," evolved during a 1-year period.

Education in dairy engineering offers a number of challenges to all constituents of the educational process-faculty, students, and employers of graduates. Quality - an essential principle and concept in the evolution of things and phenomena - has been long dealt with and thoroughly studied by specialists in various areas [26]. Quality assurance is paramount in all food manufacture and handling [27].

The present drafts regarding the quality of milk and dairy products, define it as a controlled act of creation with known accuracy that can be reached by applying constitutive control systems of the processing technologies that are present in all proceeding phases of the product.

Milk and dairy products are a major part of the human diet in many countries [28]. Most of the non- nutritional functions of milk are served by proteins and peptides which include immunoglobulin's, enzymes and enzyme inhibitors, binding or carrier proteins, growth factors and antibacterial agents [29]. The consumer has demanded a better quality product so it is the dairy producers and dairy industry's obligation to meet that request [30].

Three classes of contamination represent hazards in food, and these include: (1) biological hazards, such as bacteria, fungi and other microbial pathogens; (2) chemical hazards such as residues of medication in the lactating animal, pesticides and a variety of industrial and environmental contaminants that might contaminate the feed of the lactating animal and finally land in the milk; and (3) physical hazards such as dis-carded hypodermic needles, fragments of metal or glass and any other foreign object that may have found its way into the food, e.g. hair, feed particles, somatic cells, etc. [31].

Milk and dairy products are highly nutritious media, in which micro-organisms can multiply and cause spoilage [32]. Microbial contaminants of milk, thus, represent the organisms that exist in these animals, and their environment in which that food is produced and processed [33].

This is why the hygiene in milk industry represents an essential priority and also the appliance of a quality management system from microbiological viewpoint that includes: the co-ordination of the microbiological control activities, the planning of microbiological analysis, the development of the microbiological methods, the elaboration of the professional instruction plan for the microbiology laboratory, the development and the appliance of the air, surfaces and equipment, microbiological monitoring program needed in the production process.

The nature and manipulation of the raw milk, the hygiene conditions at the farm and the industry, the process to which it is subjected and the conditions of storage change the properties of the product [34].Nevertheless, hygiene systems designed to prevent the transfer of pathogens and more particularly to eliminate residual contamination at the completion of milking have been shown to reduce the number of new infections by about half [35].

The attempt to improve the entertainment-education strategy development process has fostered a range of approaches which have enjoyed different levels of support and popularity over time. One of the most popular is the SWOT analysis [36]. In order to achieve the purpose and to apply it in the production process by students - future specialist, we use as a teachinglearning technique the SWOT Analyze. The diagnose SWOT model can be realized by using collaboration teaching techniques - organizing small groups of students that have to give answers to the tackled issue in our paper, so that the given answers will finalize the task of the subject. The aim was to demonstrate the application of the SWOT analysis on the example of the Food Industry and Environment Protection, Department of Food Biotechnology at the "Lucian Blaga" University of Sibiu.

\section{MATERIALS AND METHODS}

In order to accomplish our study we used the SWOT Analyze. The SWOT Analyze is a very efficient one that is used in strategic planning for identifying the potentials and priorities, and used also for creating o common vision of the development strategy. This method gives the user the opportunity to identify the opportune actions to eliminate/decrease the weak points (on their hierarchical priority) and it removes the possible threats. It is a general tool designed to be used in the preliminary stages of decision- making and as a precursor to strategic planning in various kinds of applications [37, 38]. Usually, the managerial decision can be found in two forms: the decisional act and the decisional process [22].

SWOT analysis has its origins in the 1960s [39]. The technique is credited to Albert Humphrey, who led a research project at Stanford University in the 1960 s and 1970 s using data from Fortune 500 companies [40]. In more recent years SWOT analysis has been seen as somewhat outdated and superseded by resource-based planning and competency-based planning [41] For this purpose, the SWOT (strengths, weaknesses, opportunities, threats) analysis (as an instrument for examining the innovation system situation) is recommended as well as 
studying the best practices for formulating the strategies. [42]. The written SWOT analyses for courses were complemented with information obtained through interview and conversation [43].

SWOT analysis is a managerial tool used to evaluate internal and external environment through strengths and weaknesses, opportunities and threats [44]. Although the analysis successfully pinpoints the factors, individual factors are usually described briefly and very generally [45] When SWOTs are identified, strengths can be capitalized on, weaknesses minimized, and threats turned into opportunities [46]. The strengths and weaknesses are based on an "internal audit" of the organization [47].

The acronym comes from an old term from the strategic planning field that is concerned with the content and the objectives of the project, and with identifying the right things to do [48]. The word, SWOT" is an abbreviation from the following English words: S - strengths, W- weakness, Oopportunities and T-threats [49-53].

The weak points are negative aspects from the milk processing sections that can be corrected once they are detected.

The strong points are positive distinct features of the milk processing wards from microbiological viewpoint.

Table 1. Indoor conditions

\begin{tabular}{|c|c|}
\hline Strong points & Weak points \\
\hline $\begin{array}{c}\text { the use of modern standardized methods in the microbiological } \\
\text { analyses; }\end{array}$ & $\begin{array}{c}\text { the collected raw material does not correspond from } \\
\text { microbiological viewpoint; }\end{array}$ \\
$\begin{array}{c}\text { the use of modern outfit for thermic treatment; } \\
\text { respecting the UE hygiene standards in the processing sections; } \\
\text { the use of modern washing and disinfection systems; } \\
\begin{array}{c}\text { The processed raw material is of a great microbiological quality. } \\
\text { the milk collecting conditions are inadequate; } \\
\text { the milk transport in not hygienic; }\end{array} \\
\begin{array}{c}\text { The financial situation of the production section in not favorable, } \\
\text { so that the company cannot afford to buy performing outfits and } \\
\text { row material of great quality at a high price. }\end{array}\end{array}$ \\
\hline
\end{tabular}

The opportunities represent positive external environmental factors of milk processing wards. They exist for each situation presented, but they must be identified in order to establish the best strategy needed for turning them to account, especially when are taken into consideration activities of research and development in milk processing.

The threats are negative factors or negative events that can significantly affect the company's capacity in reaching it's goals.

\section{RESULTS AND DISCUSSIONS}

The SWOT Analyses has a strong quality feature that permits a correct wording of the aspects regarding technological conditions from microbiological viewpoint in the milk processing sections that reflects strong points, weak points, opportunities, threats and the generated causes or the causes that are about to be generated and then are formulated some recommendations in order to eliminate or diminish the negative aspects and to turn to account the positive ones.

The results obtained by the group of specialists that have participated to this SWOT analysis regarding the milk processing section from microbiological viewpoint are presented in the following table:

Table 2.

implementing a microbiological monitoring system of air, surfaces and the used equipment's in the processing activity; finding some sources of supplies in order buy raw material of a superior quality from microbiological viewpoint;
Threats

the high costs of the raw material that has a superior quality from microbiological viewpoint;

The strong competition between the processors in order to have their own farms at a high hygiene level.

\section{CONCLUSIONS}

The SWOT model can be used as a teaching technique through collaboration - organizing small groups of students that have to give answers to the tackled issue in our paper, so that the given answers will finalize the task of the subject.

The SWOT analysis is an efficient method that is used in the teaching technique, especially when planning the strategy in order to identify the potentials and the priorities.

\section{REFERENCES}

1. Bourne, J., D. Harris, and F. Mayadas, (2005), Online engineering education: Learning anywhere, anytime

2. Dutson, A.J., et al., (1997), A review of literature on teaching engineering design through project-oriented capstone courses. JOURNAL OF ENGINEERING EDUCATIONWASHINGTON-. 86: p. 17-28.

3. Sheppard, S., (2003), A description of engineering: an essential backdrop for interpreting engineering education. of Conference.

4. Oprean, C., et al. (2009), Innovating Engineering Education, to Face the Knowledge Society. of Conference..
5. Duse, D.M., et al. (2008), Engineering education in a highly globalised world of Conference.: WSEAS.

6. Sun, H., R.C.M. Yam, and P.K. Venuvinod, (1999), Education in engineering management. JOURNAL OF ENGINEERING EDUCATION-WASHINGTON-. 88: p. 181-184.

7. Oprean, C., et al., (2010), Paradigm shift in engineering education More time is needed. Procedia - Social and Behavioral Sciences. 2(2): p. 3580-3585.

8. Rompelman, O., (2000), Assessment of student learning: evolution of objectives in engineering education and the consequences for assessment. European journal of engineering education. 25(4): p. 339-350.

9. Wankat, P.C., et al., (2002), The scholarship of teaching and learning in engineering. Disciplinary styles in the scholarship of teaching and learning: Exploring common ground: p. 217237.

10. Mills, J.E. and D.F. Treagust, (2003), Engineering education-Is problem-based or project-based learning the answer? Australasian Journal of Engineering Education. 4(1): p. 16.

11. Bourne, J.R., et al., (1996), A model for on-line learning networks in engineering education. JOURNAL OF 
ENGINEERING EDUCATION-WASHINGTON-. 85: p. 253-262.

12. Lamancusa, J.S., et al., (1997), The learning factory-a new approach to integrating design and manufacturing into the engineering curriculum. JOURNAL OF ENGINEERING EDUCATION-WASHINGTON-. 86: p. 103-112.

13. Felder, R.M. and L.K. Silverman, (1988), Learning and teaching styles in engineering education. Engineering education. 78(7): p. 674-681.

14. Kifor, C.V., et al. (2009), Engineering Education: Dense Teaching for Life-Long Learning. of Conference.

15. Coimbra, J.S.d.R. and J.A. Teixeira, (2009), Engineering Aspects of Milk and Dairy Products. CRC.

16. Sage, A.P., (2000), Systems engineering education. Systems, Man, and Cybernetics, Part C: Applications and Reviews, IEEE Transactions on. 30(2): p. 164-174.

17. Rugarcia, A., et al., (2000), The future of engineering education I. A vision for a new century. Chemical Engineering Education. 34(1): p. 16-25.

18. Berggren, K.F., et al., (2003), CDIO: An international initiative for reforming engineering education. World Transactions on Engineering and Technology Education. 2(1): p. 49-52.

19. Jones, C. and J. English, (2004), A contemporary approach to entrepreneurship education. Education+ Training. 46(8/9): p. 416-423.

20. Giralt, F., et al., (2000), Two way integration of engineering education through a design project. JOURNAL OF ENGINEERING EDUCATION-WASHINGTON-. 89(2): p. 219-230.

21. Moisil, I., et al. (2007), e-Edu-Quality-Software Tools for Quality Management in Higher Education. of Conference.

22. Oprean, C., et al., (2009), E collaborative decisions- a DSS for academic environment. Proceedings of World Academy of Science: Engineering \& Technology. 39: p. 173-179.

23. Rotaru, M., et al., (2008), Assessing the effectiveness of education graduates in the labour market, application at the "Lucian Blaga" University- Part II. of Conference.: WSEAS.

24. Duse, D., C. Duse, and C. Deac, (2009), Emotional Intelligence-an Important Part of the Teaching Qualification in Engineering Education. of Conference

25. Oprean, C., C.V. Kifor, and N. Georgescu, (2004), Balkan Region Centre for Engineering Education (BRCEE). Global J. of Engng. Educ. 8(1)

26. Oprean, C., C.V. Kifor, and L.I. Cioca, Quality improvement in higher education institutions.

27. Walstra, P., (1999), Dairy technology: principles of milk properties and processes. Vol. 90. CRC Press.

28. Harding, F., (1996), Milk quality. Aspen Publishers.

29. Fox, P.F. and P.L.H. McSweeney, (1998), Dairy chemistry and biochemistry. Springer.

30. Johnson, A. (2000), A proper milking routine: The key to quality milk. of Conference.: National Mastitis Council; 1999.

31. Jooste, P.J. and L.E.C.M. Anelich, Safety and Quality of Dairy Products. Advanced Dairy Science and Technology: $p$. 153-182

32. Giffel, M.C. and G. Smit, (2003), Good hygienic practice in milk processing. Dairy processing: improving quality: p. $68-$ 80 .

33. O'Mahony, M., S. Fanning, and P. Whyte, (2009), The Safety of Raw Liquid Milk. Milk Processing and Quality Management: p. 139-167.
34. Belloque, J., R. Chicón, and I. Recio, (2009), Quality Control. Milk Processing and Quality Management: p. 72-100.

35. Neave, F.K., et al., (1969), Control of Mastitis in the Dairy Herd by Hygiene and Management. Journal of dairy science. 52(5): p. 696-707.

36. Hill, T. and R. Westbrook, (1997), SWOT analysis: It's time for a product recall. Long Range Planning. 30(1): p. 46-52.

37. Bartol, K.M. and D.C. Martin, (1991), Management International Edition, McGraw-Hill, New York, NY.

38. Johnson, G., K. Scholes, and R.W. Sexty, (1989), Exploring strategic management. Prentice-Hall Canada.

39. Learned, E.P., et al., (1969), Business policy: Text and cases. RD Irwin.

40. Arslan, O. and I.D. Er, (2008), SWOT analysis for safer carriage of bulk liquid chemicals in tankers. Journal of Hazardous Materials. 154(1): p. 901-913.

41. Dyson, R.G., (2004), Strategic development and SWOT analysis at the University of Warwick. European Journal of Operational Research. 152(3): p. 631-640.

42. Ghazinoory, S. and S. Ghazinoori, (2006), Developing Iran's government strategies for strengthening the national system of innovation using SWOT analysis. Science and Public Policy. 33(7): p. 529-540,.

43. Maiteny, P.T. and R.L. Ison, (2000), Appreciating systems: critical reflections on the changing nature of systems as a discipline in a systems-learning society. Systemic Practice and Action Research. 13(4): p. 559-586.

44. Terzić, Z., et al., (2010), SWOT analysis: The analytical method in the process of planning and its application in the development of orthopaedic hospital department. Srpski arhiv za celokupno lekarstvo. 138(7-8): p. 473-479.

45. Yüksel, İ. and M. Dagdeviren, (2007), Using the analytic network process (ANP) in a SWOT analysis-A case study for a textile firm. Information Sciences: an International Journal. 177(16): p. 3364-3382.

46. Miller, M.G., (2007), Environmental metabolomics: a SWOT analysis (strengths, weaknesses, opportunities, and threats). Journal of proteome research. 6(2): p. 540-545.

47. Gable, G.G., et al., (2007), Administrative placement of the Information Systems academic discipline: a comparative SWOT analysis. Communications of the Association for Information Systems. 21(Article 8): p. 137-165.

48. Sabbaghi, A. and G. Vaidyanathan, (2004), SWOT analysis and theory of constraint in information technology projects. Information Systems Education Journal. 2(23): p. 3-19.

49. Cui, T.C.W., The SWOT Analysis and Idea of the Gurbantunggut Desert Tourism Development.

50. Pahl, N. and A. Richter, (2009), SWOT Analysis-idea, methodology and a practical approach. Grin Verlag.

51. Kan, Z., C.Y.Z. Bonian, and W. Defa, (1996), SWOT Analysis of Diversified Business in Coal Enterprises. JOURNAL OF SHANDONG MINING INSTITUTE.

52. Halla, F., (2007), A SWOT analysis of strategic urban development planning: The case of Dar es Salaam city in Tanzania. Habitat International. 31(1): p. 130-142.

53. Pal, S.K. and B. Bowonder, (1979), Marketing challenges of technical industries in developing countries. Industrial Marketing Management. 8(1): p. 69-74. 